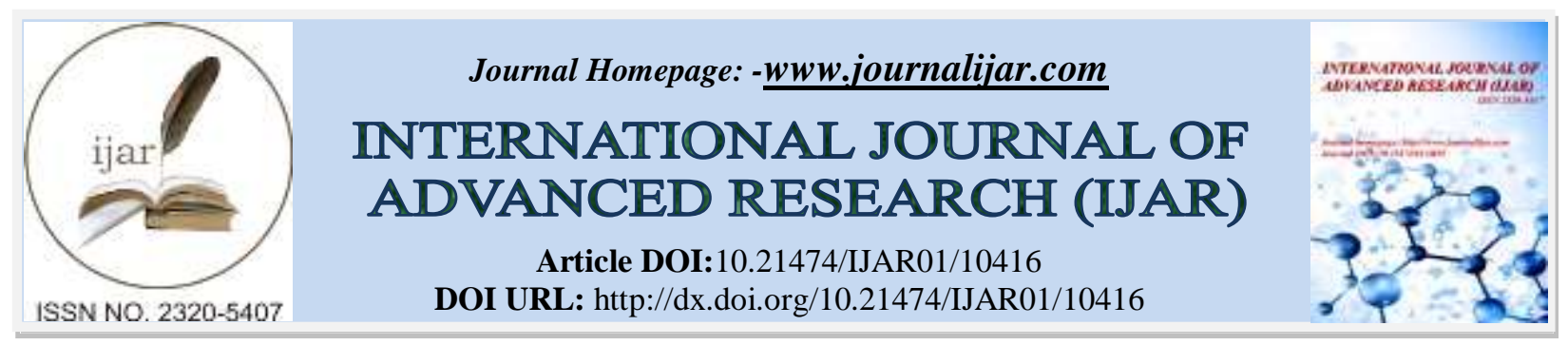

RESEARCH ARTICLE

\title{
MANAGEMENT OF TRAUMATIC HAND DEFECTS
}

\author{
Dr. S. Ganga Bhavani ${ }^{1}$ and Dr. Krishna Moorthy ${ }^{2}$
}

1. Assisstant Professor Department Of Plastic Surgery, Guntur Medical College, Guntur.

2. Consultant Plastic Surgeon, Hyderabad.

\section{Manuscript Info}

Manuscript History

Received: 30 November 2019

Final Accepted: 31 December 2019

Published: January 2020

\section{Abstract}

Copy Right, IJAR, 2020,. All rights reserved.

\section{Introduction:-}

Hand is one of the most important parts of human body due to its mechanical and sensory functions and it is one of the most developed structures in the human evolution. Intricate in design and function, hand is an amazing work of anatomic engineering. Injury to the underlying structures of the hand carries the potential for serious handicap. loss of function of the hand, or both. The loss of one's ability to work and to provide can lead to chronic depression as well as social isolation. It is therefore important that acutely injured hand is managed adequately to prevent infection, salvage the injured part, promote primary healing and restore its function ${ }^{2}$. The hand is at risk of injury from number of causes for example, road traffic accidents, burns,occupational hazards, sporting and domestic accidents. reconstruction of soft tissue defects of the hand is a challenge. The choices are local flaps or distant flaps or free flap using using microvascular techniques. Free flaps are time consuming, require specialized equipments and intensive postoperative care. Distant flaps may require multiple stage reconstruction, prolonged hospitalization and immobilization. single stage procedure to reconstruct soft tissue defects of the hand minimize infection, allow early mobilization and reduce hospital stay ${ }^{3}$. The decision on which method of wound closure should be used depends entirely on the geometry of the wound and on the local wound factors.

To reduce this risk, even the smallest hand injuries require proper and prompt intervention

\section{Materials and Methods:-}

This is a prospective study conducted in the Osmania General Hospital,Hyderabad ,Telangana.,from august 2013 to august 2015.all the patients who presented with the injury of the hand and wrist requiring reconstructive procedures were included in the study.severe mutilating injuries were excluded.

\section{Results:-}

Age wise Distribution:

According to the above table (Table I), most common age group affected by hand injuries was 21-30 years. The youngest patient in our study was 4 years old and the oldest patient was of 60 years age.

\begin{tabular}{|l|l|l|}
\hline Age Group & Number of patients & Percentage \\
\hline Upto 10 yrs & 04 & $11.43 \%$ \\
\hline $11-20$ yrs & 05 & $14.28 \%$ \\
\hline $21-30$ yrs & 10 & $28.57 \%$ \\
\hline
\end{tabular}

Corresponding Author:- Dr. S. Ganga Bhavani

Address:- Assisstant Professor Department Of Plastic Surgery, Guntur Medical College, Guntur. 


\begin{tabular}{|l|l|l|}
\hline $31-40$ yrs & 08 & $22.86 \%$ \\
\hline $41-50$ yrs & 05 & $14.28 \%$ \\
\hline $51-60$ yrs & 03 & $8.58 \%$ \\
\hline$>60$ yrs & 00 & 00 \\
\hline Total & 35 & $100 \%$ \\
\hline
\end{tabular}

\section{Sex distribution:}

in our study $88.57 \%$ (31 out of 35) patients presented with hand injury were male and only 4 patients were female.

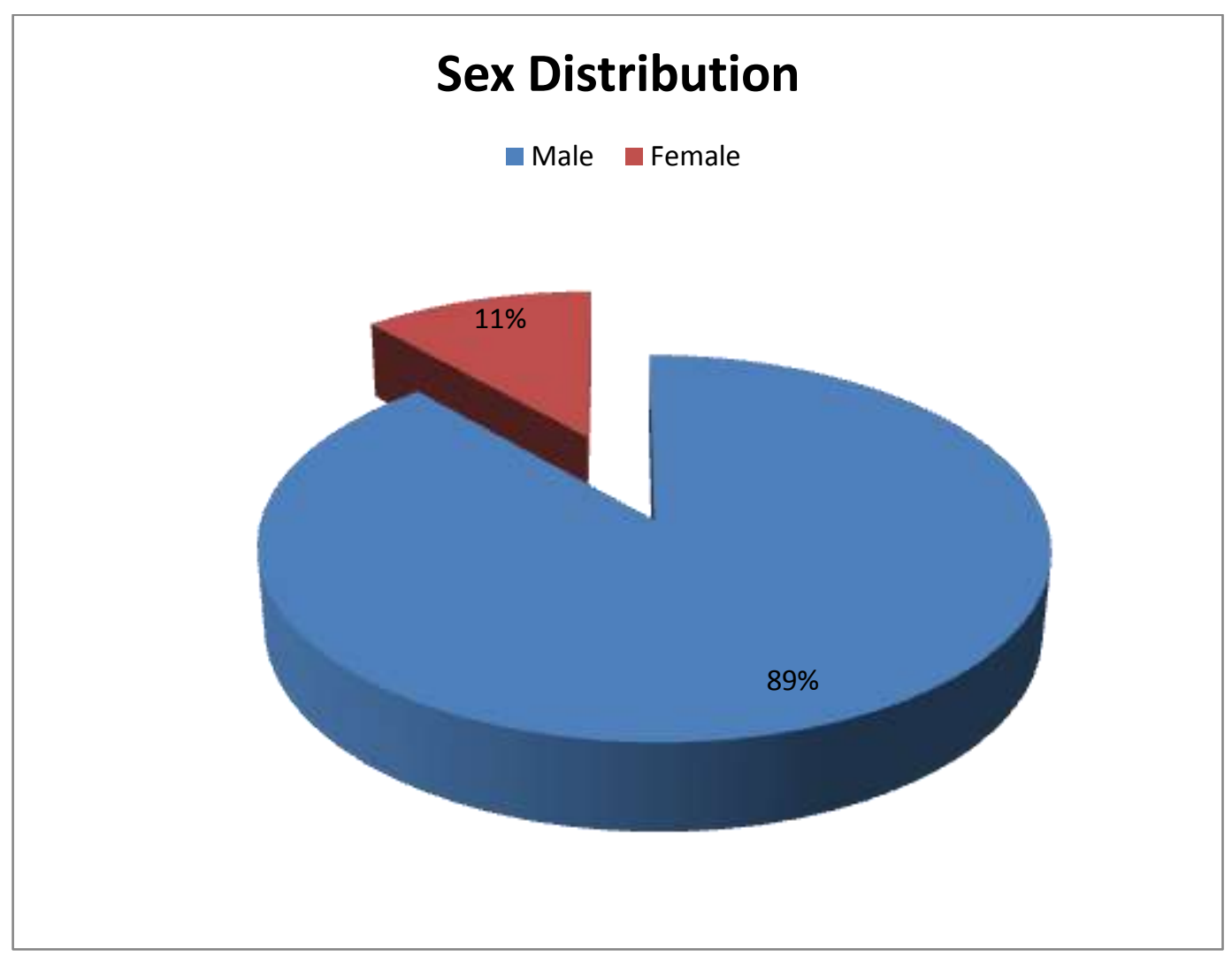

\begin{tabular}{|l|l|l|}
\hline Sex of patients & Number of patients & Percentage \\
\hline Male & 31 & $88.57 \%$ \\
\hline Female & 04 & $11.43 \%$ \\
\hline
\end{tabular}

\section{Etiology of Injury:}

According to Table III, most common cause of hand injury in our study was electric burns which was seen in $51.43 \%$ patients. Second most common cause was road traffic accident which was seen in 10 out of 35 (28.57\%) patients.

\begin{tabular}{|l|l|l|}
\hline Type of injury & Number of patients & Percentage \\
\hline Mixed flame injury & 01 & $2.86 \%$ \\
\hline Electric burns & 18 & $51.43 \%$ \\
\hline RTA (crush injury) & $10(04)$ & $28.57 \%$ \\
\hline Machinery injury & 05 & $14.28 \%$ \\
\hline Others & 01 & $2.86 \%$ \\
\hline Total & 35 & $100 \%$ \\
\hline
\end{tabular}




\section{Etiology of Injury}

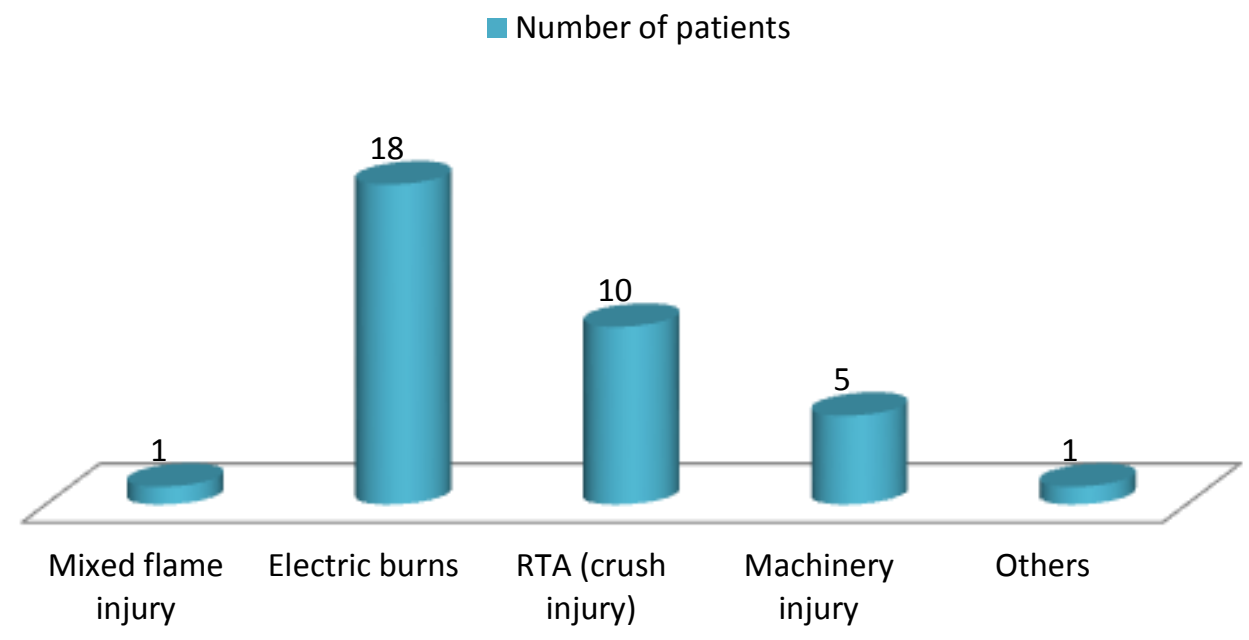

Site of Injury:

Most common site involved in different type of hand injuries was dorsum of the hand (in 62.86\%). Fingers were the second most commonly affected site seen in $28.57 \%$. Wrist was affected in 8 out of 35 patients. Thumb was involved in 2 patients while in only one patient fingertips were injuredIn our study we found that, right hand was affected in 19 patients $(54.28 \%)$ and left hand was affected in 15 patients ( $42.86 \%)$. Only one patient hand injury involving both hands.

\begin{tabular}{|l|l|l|}
\hline Site of Injury & Number of patients & Percentage \\
\hline Dorsum of hand & 22 & $62.86 \%$ \\
\hline Volar aspect of hand & 01 & $2.86 \%$ \\
\hline Wrist & 08 & $22.86 \%$ \\
\hline Fingers & 10 & $28.57 \%$ \\
\hline Thumb & 02 & $5.71 \%$ \\
\hline Fingertips & 01 & $2.86 \%$ \\
\hline
\end{tabular}

Note: more than one site is involved in some patients.

Type of Procedure:

In our study, earliest flap procedure was performed on day of injury in 4 patients. And the most delayed procedure was performed on $62^{\text {nd }}$ day of injury because of the late presentation and multiple associated injuries. . In our study, most common flap procedure performed was Hypogastric flap (37.14\%). Groin flap was the second most common procedure performed in 10 patients $(28.57 \%)$. Superiorly based abdominal flap was performed in 8 out of 35 patients. In 3 patients we performed TFL flap and in 2 patients who underwent amputation of the digit, Fillet flap was performed. Louvre flap and Pectoral flap was performed in one patient each.

\begin{tabular}{|l|l|l|}
\hline Type of procedure & Number of patients & Percentage \\
\hline Superiorly based Abdominal flap & 08 & $22.86 \%$ \\
\hline Hypogastric flap & 13 & $37.14 \%$ \\
\hline Groin flap & 10 & $28.57 \%$ \\
\hline Cross finger flap & 02 & $5.71 \%$ \\
\hline Fillet flap & 02 & $5.71 \%$ \\
\hline TFL flap & 03 & $8.58 \%$ \\
\hline Louvre flap & 01 & $2.86 \%$ \\
\hline Pectoral flap & 01 & $2.86 \%$ \\
\hline
\end{tabular}

Note: more than one procedure performed in some patients. 


\section{Type of procedure}

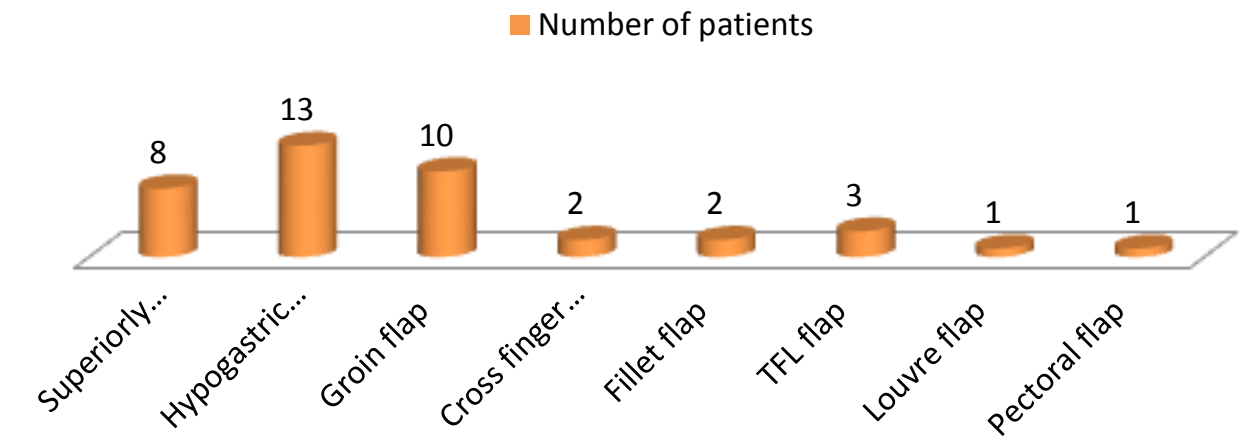

\section{Post operative Complications:}

In our study, 6 out of 35 patients (17.14\%) had partial flap necrosis. Of these 6 patients, four had partial necrosis of Groin flap and 2 had partial flap necrosis of inferiorly based Hypogastric flap. Only one patient had radial artery blow out and another had infection of the flap cover.

\begin{tabular}{|l|l|l|}
\hline Complications & Number of patients & Percentage \\
\hline Partial flap necrosis & 06 & $17.14 \%$ \\
\hline Complete flap necrosis & 00 & 00.00 \\
\hline Infection & 01 & $2.86 \%$ \\
\hline Haemorrhage & 01 & $2.86 \%$ \\
\hline Donor site Morbidity & 00 & 00.00 \\
\hline Total & 08 & $22.86 \%$ \\
\hline
\end{tabular}

\section{Complications}

Number of patients

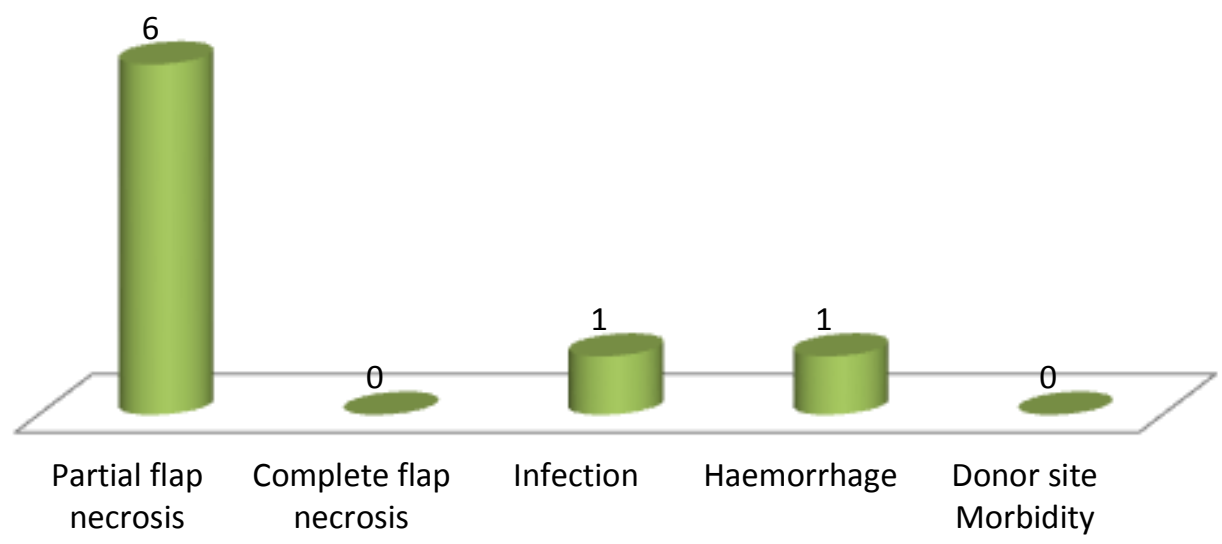

\section{Hospital stay:}

Hospital stay of the patients in our study ranged from 9 to 92 days, Most (10) of the patients were there in the hospital for 2 to 4 weeks.

\begin{tabular}{|l|l|l|}
\hline Hospital stay in weeks & No of patients & Percentage \\
\hline$<2$ weeks & 05 & $14.28 \%$ \\
\hline
\end{tabular}




\begin{tabular}{|l|l|l|}
\hline 2- 4 weeks & 10 & $28.57 \%$ \\
\hline 4- 6 weeks & 08 & $22.86 \%$ \\
\hline 6- 8 weeks & 06 & $17.14 \%$ \\
\hline 8- 10 weeks & 03 & $8.58 \%$ \\
\hline $10-12$ weeks & 02 & $5.71 \%$ \\
\hline $12-14$ weeks & 01 & $2.86 \%$ \\
\hline
\end{tabular}

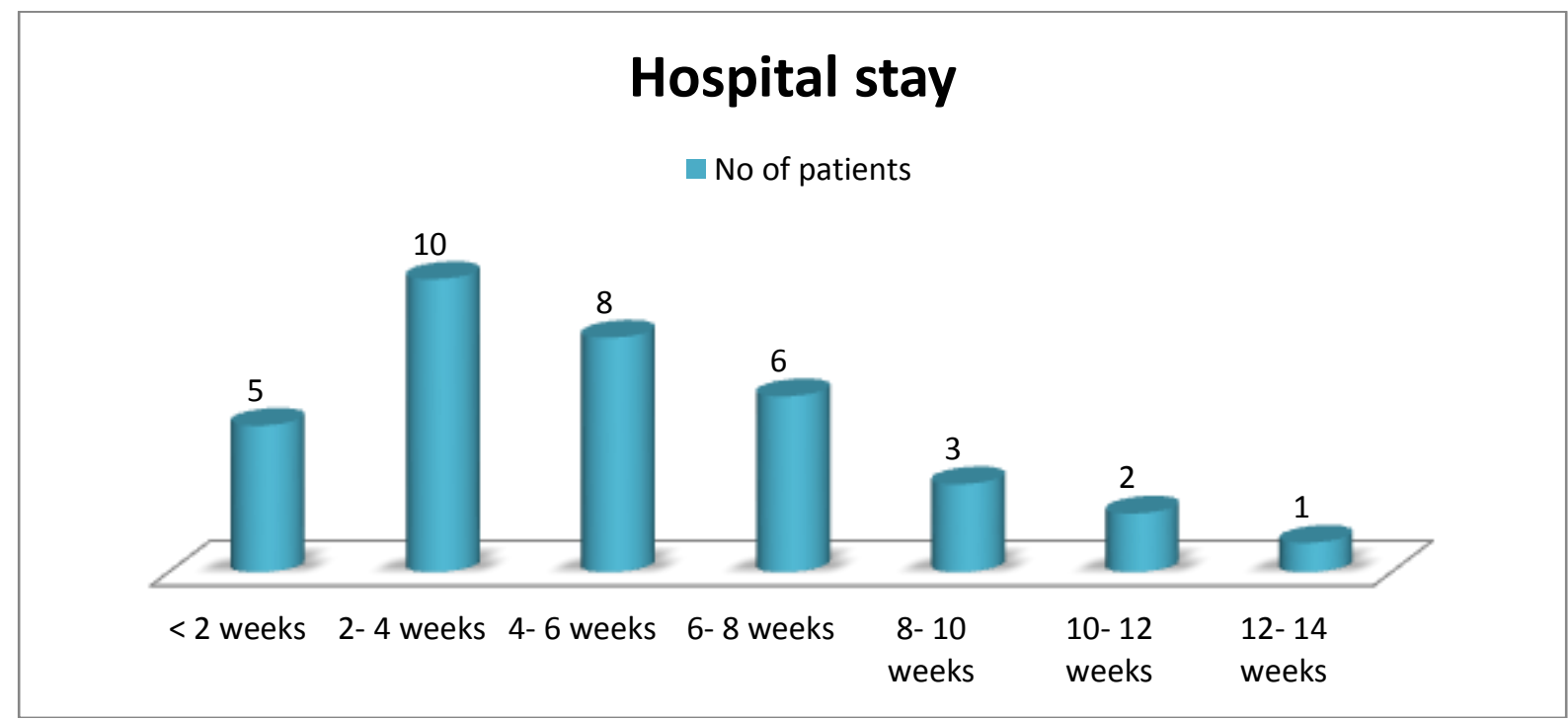

most common cause of hand defects in our study was electrical burns followed by road traffic accidents.Hypogastric flap is the commonest flap done delay between the incident and the presentation influences the outcome these injuries require many additional procedures.and result in morbidity.

\section{Discussion:-}

Any particular soft tissue defect of the hand can be managed in a variety of ways. Often the simplest procedure with the fewest potential complications suffices. Soft tissue coverage is merely one component in the management of complex hand injuries, which also may require bony stabilization, neurovascular repair and tendon reconstruction.the role of aggressive hand therapy with oedema control, early active motion, and functional retraining cannot be overemphasized. Providing stable soft tissue coverage with the potential for sensibility expands the subsequent reconstructive options and enhances the ultimate functional result.

The ideal flap procedure to reconstruct the hand defects must provide same tissue match, sensibility, low donor site morbidity, minimal scar contracture, unrestricted mobilization, easy wound care, a one stage outpatient operation and one operative field. Although this is the ideal for flaps, there is yet to be a flap that provides most of these terms 28 . The anatomy of the hand allows cover of small skin defects with a great variety of local pedicle and island flaps. However, for larger defects it is necessary that flaps from distant donor sites be used, either as free or pedicle flaps. most common cause of hand defects in our study was electrical burns followed by road traffic accidents. The common age group in our study was 21-30 years, with the age of the patients ranged from 4- 60 years. most common site of injury was dorsum of hand in 20 cases $(62.86 \%)$ followed by fingers. In our study, eight types of flap procedures were performed in 35 patients. The type of flap procedure was decided depending on patient's comfort, site and size of defect.

\section{References:-}

1. Littler JW, Plastic Surgeons and the Development of Hand Surgery. In: Thorne C.H. (ed) Grabb and Smith's Plastic Surgery 6th edition. Lippincott, William, Philadelphia 2007: 737-740.

2. Emmanuel $\mathbf{J}$ K Adu. Management of hand injuries: A six year experience from Komfo Anokye Teaching Hospital, Kumasi, Ghana. Postgraduate Medical Journal of Ghana 2013; 2 (2) 
3. Muhammad Naveed Shahzad, Naheed Ahmed, Khalid Husssain Qureshi. Reverse flow posterior interosseous flap: Experience with 53 flaps at Nishtar Hospital, Multan. J. Pak Med Assoc 2012; 62 (9): 950-954.

4. BY Jerome D. Chao, Josephine M Huang, Thomas A Wiedrich. Local hand flaps. J of American Society for surgery of the Hand 2001; 1(1): 25-44.

5. Clarence A. McWilliams. Plastic flap from the abdomen for burn of the hand. Annals of Surgery 1917; 66.

6. George Warren Pierce, Gerald Brown O' Connor. Pedicle flap patterns for hand reconstruction. S.G.O. 1937; 65: 523-527.

7. Darrel T. Shaw, Robert L. Payne. One stage abdominal tubed flap. Surgical Clinics of North America 1944; 293-308.

8. Atasoy E, Loakimidis E, Kasdan ML, et al. Reconstruction of the amputated finger tip with a triangular volar flap: A new surgical procedure. J Bone Joint Surg Am 1970; 52: 921-926

9. Kutler W. A new method for fingertip amputation. J Am Med Assoc 1947; 133: 29-30

10. Cronin T. The cross finger flap: A new method of repair. Am Surg 1951; 17: 419-425

11. Holevich J. A new method of restoring sensibility to the thumb. J Bone Joint Surg Br 1963; 45: 496-502.

12. Holevich J. A new method of restoring sensibility to the thumb. J Bone Joint Surg Br 1963; 45: 496-502

13. Moberg E. Aspects of sensation in reconstructive surgery of the upper extremity. J Bone Joint Surg Am 1964; 46: $817-825$

14. Hueston J. Local flap repair of fingertip injuries. Plast Reconstr Surg 1966; 37: 349.

15. Melone CP, Beasley RW, Cartsens JH. The thenar flap - an analysis of its use in 150 cases. J Hand Surg 1982; 7: 291-297.

16. McGregor IA, Jackson IT. The groin flap. Br J Plast Surg 1972; 25: 3.

17. Joshi BB. A sensory cross finger pedicle graft. J Bone Joint Surg 1976; 58: 210-213.

18. Yang G, Chen B, Gao Y, et al. Forearm free skin flap transplantation. Natl Med J China 1981; 61: 139.

19. Foucher G, Braun JB. A new island flap transfer from the dorsum of the index finger to the thumb.Plast Reconstr Surg 1979; 63: 344-349.

20. Venkataswami R, Subramanian N. Oblique triangular flap: A new method of repair for oblique amputations of the fingertip and thumb. Plast Reconstr Surg 1980; 66: 296-300.

21. Chang TS, Wang W. Application of microsurgery in plastic and reconstructive surgery. J Reconstr Microsurg 1984; 1: 55-63.

22. Lai CS, Lin SD Yang CC. The reverse digital artery flap for fingertip reconstruction. Ann Plast Surg 1989; 22: 495-500.

23. Kjomia T, Tsuchida Y, Hirase Y et al. Reverse vascular pedicle digital island flap. Br. J Plast Surg 1990; 43: 290-295.

24. Wintsch K, Helaly P. Free flap of gliding tissue. J Reconstr Microsurg 1986; 2: 143-151.

25. Zancolli EA, Angrigiani C. Posterior interosseous island flap. J Hand Surg 1988; 13: 130-135. 